\title{
Emotional and Volitional Component of Formation of the Technical University Students' Cognitive Independence: Diagnostic Study Results
}

\author{
Elena KABANKOVA \\ Ph.D. (in Pedagogical Sciences) \\ Associate Professor \\ Department of Foreign Languages \\ Institute of Social Sciences and International Relations \\ Sevastopol State University \\ 33, Universitetskaya str., Sevastopol, 299053, Russia \\ +7 (8692) 43-51-95 \\ lenatatushko@rambler.ru
}

\begin{abstract}
This article is about the essence and content of the concepts of "emotion" and "will", the constituents of the cognitive independence. The latter is considered to be an integrative property of people related to their ability and desire to carry out purposeful independent cognitive activity. So, the emotions that a person experiences in everyday life affect individual and social development and the formation of interpersonal relationships, express the state of the subject and its attitude to the object. The will contributes to the implementation and bringing the action to the final result, overcoming the internal obstacles. There have been identified positive and negative emotions, as well as the main volitional qualities that need to be learned by technical university students. The main structural components of the technical university students' cognitive independence are highlighted. The levels of the personality criterion of the emotional and volitional component are formulated. In the work, the methodology of revealing the formation of the emotional and volitional component of the formation of technical university students' cognitive independence is highlighted. The features of the research and experimental work control phase of the pedagogical experiment are disclosed. The results of the study can be used to develop special courses, teaching aids, when course and master papers writing.
\end{abstract}

Keywords: emotion; will; cognitive independence; pedagogical experiment; ascertaining phase; control phase. 


\section{Introduction}

Global changes and dynamism in the cultural and educational spheres of society's life necessitate the formation of a competent, competitive, socially active person who is able not only to adapt to a new situation, but also able to change it, engaged in self-education depending on the requirements of the time and situation. The ability to transform concerns all aspects of human life, but it is especially manifested in professional activities. Therefore, continuous improvement of knowledge is possible only with high independent cognitive activity of a person, students in particular.

That is why higher education institutions need to ensure the constant personal growth of future specialists in the context of independent training, to develop an effective attitude to the future profession and the desire for self-improvement and self-development. The development and formation of cognitive independence, cognitive interests of students will make it possible to independently formulate and set goals, make decisions, bear responsibility for their actions and the results achieved.

Literature review. The pedagogical aspects of the problem of the formation of cognitive independence were considered in the studies of such scientists as Aristova, Vyatkin, Halperin, Yesipov, Lerner, Makhmutov, Polovnikova, Talyzina, Schukin. In their works questions of understanding the essence, structure and levels of development of students' cognitive independence, the means of its formation are developed.

The objective of the article is to highlight the methodology for determining the formation of the emotional and volitional component of technical university students' cognitive independence.

\section{Methods}

Theoretical: analysis of philosophical, psychological and pedagogical, educational and methodical literature; generalization; comparison, classification and systematization of theoretical data. Empirical: survey, pedagogical observation, comparison, generalization, conversation, questioning. Pedagogical experiment: ascertaining and formative phases.

\section{Results}

Diagnosis is an important component of the educational process as it helps to achieve goals. It is impossible to effectively manage the didactic process, and then to determine its results accurately without it. In particular, according to Babansky (1977), “... the very structure of the learning process 
involves the functioning of the feedback component, without which it is impossible to provide regulation and adjustment of this process, design and specification of new learning objectives".

In the encyclopedia, the term "diagnosis" is defined as "recognition ability" (Bolshaya sovetskaya enciklopediya, 1972). It should be noted that pedagogical diagnostics helps to identify the prerequisites, conditions and results of the pedagogical process in order to optimize it. With its help, the educational process is analyzed and learning outcomes are determined.

It should be noted that the formation of technical university students' cognitive independence is ensured by its structural components (aim-motivational, content-operational, emotional and volitional, evaluative). They are closely interconnected and inalienable to each other. In this article, the emotional and volitional component is considered in more detail. It is based on the willingness of subjects to carry out volitional efforts to overcome cognitive difficulties and its implementation in independent cognitive activity.

The interconnection of the emotional and volitional spheres of the personality lies in the fact that "the social individual must be able to manage his/her emotional sphere, mastering the external and internal means of regulation of strong effective states" (Dormashev, Kapustin, Petukhov, 2002). Emotions express the state of the subject and its attitude to the object. In complex human feelings, they often form a complex, contradictory unity.

Thus, emotions, being central in our lives, arise both in the form of mass phenomena, and in small groups and in dialogs. The way people cope with each other and their environment is largely determined by emotions. Emotions shape everyday experience and behavior: there is hardly a day when we do not experience any emotions.

Emotions belong to a special class of mental processes and conditions that serve as the organizing and motivating factor in human behavior. They regulate behavior and activities (including cognitive) from within, constantly correlating their course and intermediate results with needs and motives. Emotions are a subjective (mental) form of existence of needs (Rubinshtejn, 1989). This indicates a close relationship of emotions with needs and motives.

In a large psychological dictionary, ed. Zinchenko (2009), the concept of "emotion" is interpreted as "a special class of mental processes and conditions associated with instincts, needs, motives and reflecting in the form of direct experience the significance of phenomena and situations acting on the individual for the implementation of his/her life".

In general, it should be noted that "emotions are more ancient ("primary") form of reflection than significantly more conscious, speech-mediated cognitive processes, and their main purpose is to 
signal the benefits or harms of a given phenomenon. This assessment of the sign of the phenomenon (positive or negative) is believed to be primary" (Homskaya, 1998).

Yanovskaya (1998) believes that any educational method should include emotionally "filled" pedagogical tools. Emotions stimulate, "saturate" the method, as a result of this, the student's active attitude to the activity is formed.

Much attention is given to the study of the influence of emotions on the learning process in higher educational institutions in foreign studies. The importance of emotions in learning can be traced in the works of Mezirov (1978), who believes that one cannot go beyond a complex problem without first encountering negative emotions such as anger, guilt, or sadness. In the educational process, it is necessary to deal with all emotions, as its important constituent (Dirxx, 2006; Hartley, Woods, Pill, 2005; Henderson, Nathenson, 1984). Students should develop appropriate emotional inclinations and habits of the mind in order to feel the appropriate emotions at the right time and in relation to the corresponding objects, and also rely on these frameworks to make sense of their surroundings (Benesch, 2012; Maiese, 2017; Richards, Rodgers, 1999).

It is also important to pay special attention to "positive" emotions when teaching students, trying to smooth out "negative" emotions and encouraging the development and formation of "positive" emotions, such as happiness, joy and excitement (Bearda, Humberstone, Clayton, 2014).

Therefore, emotions are an internal regulator of activity that serves as the organizing and motivating factor in human behavior. They are formed in the course of human activity aimed at meeting the needs, thus arising in the activities of the individual, they become a motive for activity. Emotions, as a manifestation of need, thus express its active side.

In the structure of cognitive independence formation, we single out positive emotions (joy, pleasure, confidence, pride, dignity, surprise) and negative (fear, resentment, chagrin, boredom, anxiety). In the learning process, they are manifested in the features of speech, facial expressions, motor skills. Therefore, it is the emotion that is the tool setting up a person to communicate with the world, with other people, with himself/herself.

The emotional manifestations of independence, in particular cognitive, of students due to agerelated characteristics are directly dependent on their individual and psycho-physiological characteristics. Positive emotions have a great influence on the activities of people, especially those with increased emotionality. The pleasure of active independent cognitive activity causes the greatest emotional response. Thus, successfully completed work provides emotional strength, it is a powerful incentive for further activities. 
Independent advancement in cognition, even if there is a desire to master knowledge and methods of activity, may not take place if the individual does not carry out a certain voluntary effort to achieve it. As indicated by Selivanov (1992), "the ability to overcome difficulties of fulfillment is the main indicator of assessing the willful development of a person".

The presence of the will is inextricably linked with the existence of important aims and objectives for the individual. Setting and accepting a goal is the stage that determines the further volitional efforts of a person to achieve it.

Willful aspirations and efforts characterize the cognitive activity of a student at all its stages. According to Rubinstein (1989), "the beginnings of the will are already contained in the needs as in the initial impulses of a person to action". These words convincingly show that need determines the connection of motives and volitional processes with emotions.

So, the motive induces, stimulates, gives the meaning of activity, and the will contributes to the implementation and bringing the action to the final result.

We agree with the opinion of Kozakov (1990) regarding the allocation of the following stages of volitional action:

- awareness of the goal and the desire to achieve it;

- awareness of a number of opportunities to achieve the goal;

- the emergence of motives that affirm or deny these opportunities;

- struggle of motives and choice;

- adoption of one of the possibilities to achieve the goal as a solution;

- implementation of the decision made.

The decisive stage is the struggle of motives, as a result of which the choice is determined and, in fact, a strong-willed decision appears. In this case, a manifestation of the will may occur (the students forced themselves to do something, despite the obstacles) or weak will (the preference is for the motive "I want" or "I don't want", rather than the motive "I need"). In the latter case, there is a mismatch of purpose and motive, weak will is manifested.

It is important to note that students with a strong will are clearly aware of the goals and how to achieve them. If at the same time they have sufficient opportunities and motives, then the struggle of motives and choice takes place reasonably and quickly, decisions are always reasoned and with an intense desire, stability and activity are manifested in their implementation. 
In our opinion, technical university students need to cultivate such strong-willed qualities: activity, determination, discipline, organization, perseverance in achieving goals, determination, initiative, confidence, sociability, self-confidence, independence in decision-making, responsibility for own decisions, self-criticism, readiness for action and cooperation, mobility. Other volitional qualities that are directly opposite to independence (stubbornness, suggestibility, indecision, weakness, lack of initiative, etc.) must be put into action.

Since "cognitive independence" is a multifaceted concept, to determine its general, integral level, we have formulated the following levels (creative, productive, reproductive) of indicators of the personal criterion of the emotional and volitional component. Despite the fact that each component of the cognitive independence is characterized by many indicators, we have analyzed the individual, the most important and generalized ones.

In the process of the pedagogical experiment there has been used the technique that provides the identification of the emotional attitude to educational activity and professionally important volitional qualities of students. For this purpose, the following methods have been used: pedagogical observation, comparison, generalization, conversation, questionnaire, survey.

Assessment of the state of the emotional and volitional component has been carried out on the basis of a personal criterion, including the following indicators: the formation of professionally important and necessary qualities for the implementation of professional activities; awareness of the importance of their activities; readiness for action.

In the context of our study, in order to determine the initial level of formation of technical university students' cognitive independence, the ascertaining stage of the pedagogical experiment has been conducted. Its purpose is to study, analyze and evaluate the real state of formation of the designated phenomenon.

Let us dwell in more detail on the study of the volitional component. Thus, technical university students have been asked to answer fifteen questions in the questionnaire "Self-Assessment of Willpower". If they agree with the content of the question, students need to write "yes", if they doubt or are unsure - "I don't know" (or "happens"), if they do not agree - "no".

Questionnaire text:

- Are you able to complete the work that you have begun that is not interesting to you, regardless of the fact that time and circumstances allow you to break away from it and then return to it again?

- Have you overcome internal resistance without much effort when you have to do something unpleasant for you (for example, go on duty on a weekend)? 
- When you find yourself in a conflict situation at work or at home, are you able to pull yourself together enough to look at it with maximum objectivity?

- If you are prescribed a diet, can you overcome all the culinary attractions?

- Will you find strength in the morning to get up earlier than usual, as was planned in the evening?

- Will you stay at the scene to testify?

- Do you respond quickly to letters?

- If you are afraid of an upcoming flight by plane or visiting a dental office, will you be able to overcome this feeling without much difficulty and not change your intention at the last moment?

- Will you take a very unpleasant medicine that your doctor recommended?

- Do you keep this promise in a breeze, even if its fulfillment will bring you a lot of trouble? Are you the person of the word?

- Do you hesitate to go on a trip to an unfamiliar city, if necessary?

- Do you strictly adhere to the daily routine: time of awakening, eating, exercising, cleaning and other things?

- Do you disapprove of library debt?

- Won't the most interesting TV show make you delay the execution of urgent and important work? Is it so?

- Will you be able to break off a quarrel and shut up, no matter how offensive the words of the opposite side may seem to you?

\section{Discussion}

The results of the survey have revealed the following indicators of the formation of the volitional potential of the respondents: creative $-1.8 \%$; productive $-40.9 \%$; reproductive $-57.3 \%$, that is, the analysis of the data obtained convincingly proves that the largest number of respondents according to the results of the ascertaining phase of the experiment has been at the reproductive and productive levels of the formation of cognitive independence.

The implementation of such a didactic condition as the intensification of a positive emotional and volitional attitude of future engineers in the process of independent cognitive activity has contributed to the fact that independent activity brings pleasure and joy from learning new things, as 
well as the formation of professionally important and necessary for the implementation of professional activities personality traits, ready for actions (Kabankova, 2019).

First of all, it is worth paying attention to the type of study room, which should both motivate students of a technical university and bring emotional and aesthetic pleasure.

It is important to consider the teachers' emotional behavior, their goodwill and respect for students. Classes should be started with a smile, looking into the eyes of each student.

To overcome the fear and uncertainty of technical university students of, one can use certain techniques to express their thoughts, in particular, "group joy", "horizon lines", "advance payments", creating a "success situation", “announcing", "follow them". The use of stimulation methods also contributes to the creation of a favorable emotional microclimate, the formation of the volitional qualities of future engineers in the classroom. These include game methods, competitions, rewards and punishments.

The positive dynamics of the levels of formation of technical university students' cognitive independence has been recorded after the formative phase of the pedagogical experiment for the personal criterion. The data obtained are presented in Table 1, which indicates a significant change in the indicators of the manifestation of the personality criterion in the experimental group, in contrast to the control group: at the creative level there has been $42.7 \%$ (at the ascertaining phase $1.8 \%$ ), at the productive level $-44.6 \%$ (at the ascertaining phase $-40.9 \%$ ); at the reproductive level $-12.7 \%$ (at the ascertaining phase $-57.3 \%$ ).

Table 1. Generalized experimental results (in \%)

Criterion of students' cognitive independence
Levels

Groups Phases

Reproductive Productive Creative

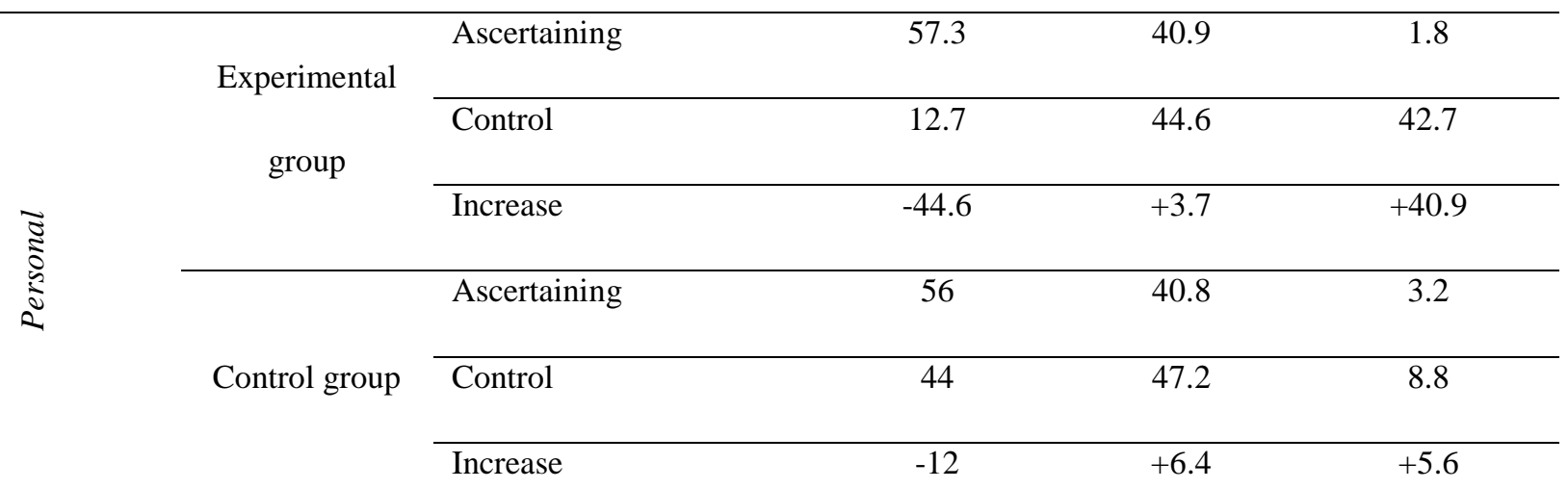




\section{Conclusion}

Thus, the positive emotional and volitional attitude of technical university students towards learning plays an important role, since it includes creating a comfortable climate in the audience, situations of success, teacher's friendly attitude, activating the desire for self-education, contributing, first of all, to the formation of cognitive independence. Theoretical conclusions and experimental results can be used to develop special courses, write teaching aids and guidelines for the formation of cognitive independence of technical university students, while course and master's papers writing, in the system of postgraduate education system.

\section{References}

Babanskij, Y.K. (1977). Optimizaciya processa obucheniya. Moskva: Pedagogika. (in Russian)

Bearda, C., Humberstone, B., Clayton, B. (2014). Positive emotions: passionate scholarship and student transformation. Teaching in Higher Education, 19(6), 630-643.

Benesch, S. (2012). Considering emotions in critical English language teaching: theories and praxis. Routledge, New York.

Bolshaya sovetskaya enciklopediya. (1972). Moskva: Sovetskaya enciklopediya, 8. (in Russian)

Dirxx, J. (2006). Engaging emotions in adult learning: a Jungian perspective on emotion and transformative learning. New Directions for Adult \& Continuing Education, 109, 15-26.

Dormashev, Y.B., Kapustin, S.A., Petukhov, V.V. (2002). Obshaya psihologiya, 2. Moskva: UMK Psihologiya; Genezis. (in Russian)

Hartley, P., Woods, A., Pill, M. (2005). Enhancing Teaching in Higher Education. New Approaches for Improving Student Learning. Oxford: Routledge.

Henderson, E.S., Nathenson, M.B. (1984). Independent learning in higher education. Englewood Cliffs. New Jersey: Educational Technology Publications, 3-56.

Homskaya, E.D. (1998). Mozg i emocii: nejropsihologicheskoe issledovanie. Moskva: Ros.ped. agentstvo. (in Russian)

Kabankova, E.N. (2019). Algoritm realizacii didakticheskih uslovij formirovaniya poznavatelnoj samostoyatelnosti studentov tehnicheskogo universiteta $\mathrm{v}$ processe izucheniya inostrannogo yazyka. CITISE, 1(18), 23. (in Russian)

Kozakov, V.A. (1990). Samostoyatelnaya rabota studentov i ee informacionno-metodicheskoe obespechenie. Kiev: Vysha shk. (in Russian) 
Maiese, M. (2017). Transformative learning, enactivism, and affectivity. Studies in Philosophy and Education, 36(2), 197-216.

Mesheryakova, B.G., Zinchenko, M.P. (2009). Bolshoj psihologicheskij slovar. Moskva: AST. (in Russian)

Mezirow, J. (1978). Perspective transformation. Adult Education, 28(2), 100-110.

Richards, J.C., Rodgers, T.S. (1999). Approaches and Methods in Language Teaching. Cambridge: Cambridge University Press.

Rubinshtejn, S.L. (1989). Osnovy obshej psihologii, 2. Moskva: Pedagogika. (in Russian)

Selivanov, V.I. (1992). Izbrannye psihologicheskie proizvedeniya: volya, eyo razvitie $i$ vospitanie. Ryazan: Izd. Ryazanskogo gos. ped. instituta. (in Russian)

Yanovskaya, M.G. (1998). Emocionalno-cennostnye tehnologii nravstvennogo vospitaniya. Kirov: Izd-vo VGPU. (in Russian) 